\title{
Agricultural Impacts of Climate Change and the Climate Change Adaptations- A Nepalese Context Review
}

\author{
Sudhan Bhusal* \\ College of Natural Resource Management, Puranchaur, Kaski, Nepal \\ *Corresponding Author: Sudhan Bhusal, College of Natural Resource Management, Puranchaur, Kaski, Nepal.
}

Received: May 27, 2019; Published: June 26, 2019

DOI: $10.31080 /$ ASAG.2019.03.0550

\begin{abstract}
Production of Greenhouse gases are responsible for the negative impacts on crop productivity. Change in temperature, precipitation and composition of gases have greater potentials to affect the crops and they are being affected till date. Severe cases have been seen in different places countrywide. Rarity of different crop varieties like Amaranthus, Millets etc. are all caused due to the climate change. On an average the temperature increase in Nepal was recorded as $0.06^{\circ} \mathrm{C}$ per year in which increment in Terai and Himalayas was $0.04^{\circ} \mathrm{C}$ and $0.08^{\circ} \mathrm{C}$ per year respectively. NARC shows Cold wave due to severe winter in 1998 caused high percentage of yield reduction for potato (27.8\%), leaf mustard (36.5\%), mustard seed (11.2\%), lentil (37.6\%), and chickpea (38\%). Reduction in the potential of productive lands due to floods, landslides and erosion are also the issues at peak. Every year, flood sweeps a huge amount of productive lands in Terai whereas the lands in hills are fallow due to rain deficit. Various steps are being taken by government to adapt to climate change. Several policies are made. Some of the policies are implemented and some are yet to be implemented. But, now is the time to be serious about climate change and to find proper adaptive measures to reduce its effects.
\end{abstract}

Keywords: Climate; Climate Change; Agriculture; Climate Change Adaptations

\section{Introduction}

Nepal is a country of unlimited biodiversity in different perspectives. The diversity rests within the plant species too. Nepal is situated on the southern slopes of the central Himalayas. Nepal's great biodiversity is associated with the country's exceptional diversity of topographic, climatic, and agro-ecological conditions. According to these conditions, Nepal is divided into four main physiographic zones [1]. High Himal (above 5000 masl.); High Mountains (30005000 masl.) with alpine or sub-alpine climate; Mid-Hills (1000 3000 masl.) with temperate or subtropical climate, and Lowlands (below 1000 masl.) with tropical climate.

Due to the diversity in topography, many different species of plants are available in Nepal. Either they are cultivated species or they are wild species. Many species of vegetables, Fruits, medicinal plants and many other plants are found here. Plants that thrive in cold region as well as plants that thrive in warmer regions can be successfully cultivated. Perhaps, Topography is the boon. In Nepal, between 5800 and 6500 species of flowering plants [2] have been estimated, about 1500 of which are considered useful [3]. Out of these, 651 species are economically useful including 440 species of wild food plants. As a result of diverse agro-ecological and socio- economic conditions high crop genetic diversity at farm level can be observed [4].

Nepal is an agricultural country having 66 percent people directly engaged in farming [5] and agriculture contributes about 36 percent in the Nepalese GDP [6]. Maize, millet, wheat, barley and buckwheat are the major staple food crops. Similarly, oilseeds, potato, tobacco, sugarcane, jute and cotton are the important cash crops whereas lentil, gram, pigeon pea, black gram, horse gram and soybean are the important pulse crops. Nepal is also famous for orthodox tea, large cardamom, turmeric and zinger too. Most Nepalese farmers grow diversified crops in order to hedge against erratic and uncertain weather and other unfavourable agronomic conditions [5].

Climate Change can be illustrated as the phenomenon that includes change in environmental factors like temperature, humidity, precipitation and others over a long period of time due to emission of greenhouse gases majorly caused by the burning of fossil fuels. Burning of fuels and woods cause in the release of harmful gases like carbon dioxide, sulfur dioxide as well as the carbon monoxide and many other gases that are relatively proportional to the increase in the temperature of the earth surface that causes climate 
change. In Nepal, traditional way of cooking by burning fire woods is prevalent. And, forests are being cut down for the fire woods as well as to clear the land for agricultural purposes. As a developing country, there were no any privileges of biogas and LPG-gas. Because of this, farmers were totally dependent upon the forests and fire woods for cooking. This released many toxic gases on the atmosphere.

Nepal, being a small country and occupying a small area in the globe, contributes less to the climate change but is in great threat to the effects caused by the climate change in near future. Nepal is rich in water resources which if polluted, can cause degradation or even eradication of the aquatic plants and animals. Even the terrestrial plants can face different problems. Whereas, animals are believed to be facing many different disorders and diseases due to the increasing temperature and increasing UV-rays unfolded from the almighty solar radiations. Even, some of the symptoms are being seen throughout the country nowadays. People are affected by cancer on various organs of the body.

Agricultural sector has been affected more by the climate change in Nepal. Nepal used to be a rice exporter country in the past whereas it is one of the importers. Amidst the millennium development goals and agriculture perspective plan (APP) 1996-2015, Nepal always faced food grains deficit in more than 27 districts in the hill and high hill regions [7]. There are many agronomical as well as horticultural crops whose yield per unit area is decreasing in comparison to the past. Agricultural lands which provided enough nutrients to the crops are also in a diminishing due to the maximum soil temperature. Crop losses due to severe floods, extended droughts, emergence of diseases and proliferation of insect pests, all of which are closely related to the impacts of climate change, have been increasing both in coverage and frequency in recent years. The flood events in the southern part of the country on $\mathrm{Au}$ gust 11-14, 2017 wiped out crops worth Rs. 8.11 billion rupees in 14 districts that are known as bread basket of the country [8].

\section{Material and Methods}

This paper is based on the review of different national and international papers related to agriculture and it, being affected by climate change. Secondary data regarding the climate change and its affect on the various growing stage of crops were collected. The national documents, policies, plan, strategies, brochure, booklets, reports, program, projects, research results and published reports related to agriculture and climate change were collected from the concerned directorates, office, projects as well as official websites.

Collection, scanning and sorting of the useful information was done during the reviewing in detail. Climate change, Agriculture affected by climate change related materials were noted and taken into priority for the study from international journals. But, a thorough study about Nepalese data's, policies, strategies and programs is also done in brief.

\section{Discussions}

Various data regarding climate change i.e. change in annual temperature, annual precipitation have been studied during the review. In Nepal, average temperature increase was recorded as $0.06^{\circ} \mathrm{C}$ per year and that in Terai and Himalayas was $0.04^{\circ} \mathrm{C}$ and $0.08^{\circ} \mathrm{C}$ per year respectively [9]. It is expected that by $2090 \mathrm{~s}$, average temperature in Nepal will increase by 3.0 to $6.3^{\circ} \mathrm{C}$ with a multimodel mean of $4.7^{\circ} \mathrm{C}$ [10]. However, [11] estimated that the rise in temperature in Nepal will be by 0.5 to 2 by the 2030, 1.3 to 3.8 by the 2060 and 1.8 to 5.8 by the 2090 . And, it has been estimated that the annual precipitation changes by -34 to $+22 \%$ by the 2030 s, -36 to $+67 \%$ by the 2060 s and -43 to $80 \%$ by the 2090 s [11]. Even the increase in the monsoon rainfall was estimated as -14 to $40 \%$ by the 2030 s, -40 to $+143 \%$ by the 2060 s and -52 to $135 \%$ by the 2090s [11]. Similarly, Study done on $\mathrm{CO}_{2}$ enrichment technology at Khumaltar, Nepal revealed that the yield of rice and wheat increased by $26.6 \%$ and $18.4 \%$ due to double $\mathrm{CO}_{2}, 17.1 \%$ and $8.6 \%$ due to increase in temperature respectively [12].

Chart- 1 deals with the average change in maximum temperature of Nepal as a whole. This shows that the average annual maximum temperature is increasing. This means every year; temperature is rising by a certain degree. For instance, the average annual maximum temperature of Nepal in 2012 was 20.3236 which is highest till date whereas the average annual maximum temperature of $\mathrm{Ne}$ pal in 2015 was reported to be 19.422 . The slope of the trendline is positive which means that the average annual maximum temperature is increasing.

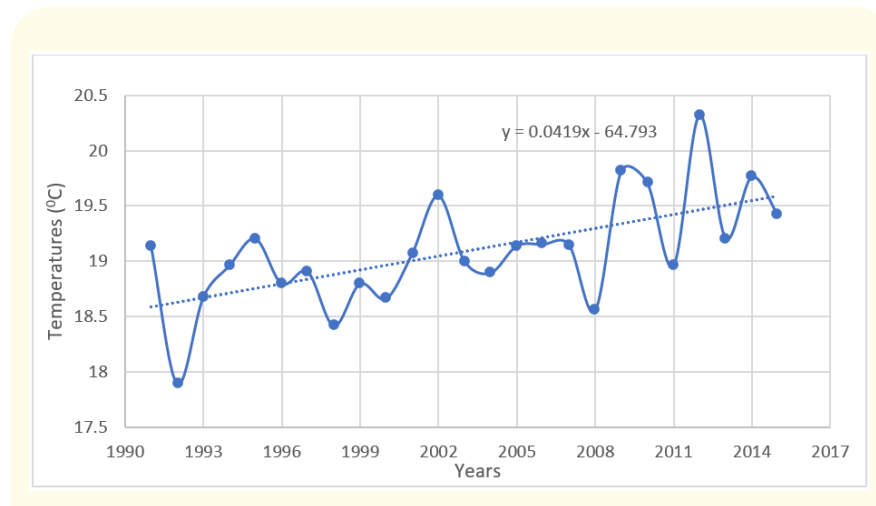

Chart 1: Average annual maximum temperatures in Nepal. (1991-2015).

Effect of maximum temperature is seen in different crops during their different stages of growth. The temperature required for a crop during a vegetative phase of growth is higher than the requirement during the reproductive phase. Studies have shown that the 
increasing temperature mainly affects the pollination stage of plant growth. The effect of temperature is enhanced under high vapor pressure deficits because pollen viability (prior to silk reception) is a function of pollen moisture content which is strongly dependent on vapor pressure deficit [13]. Exposure to temperatures above $30^{\circ} \mathrm{C}$ damaged cell division and amyloplast replication in maize kernels which reduced the size of the grain sink and ultimately yield [14]. In case of response of pollen viability to temperature, the response of Rice is also found to be similar with that of maize. Similarly, Increase of temperature may cause yield declines between $2.5 \%$ and $10 \%$ across a number of agronomic species throughout the $21^{\text {st }}$ century [15]. Various evaluations regarding the temperature and crop yields have shown that there is negative response of yield with increasing temperature.

Chart- 2 deals with the average annual minimum temperatures of Nepal. The slope of the trendline of the graph is positive which shows that the average annual minimum temperature of Nepal is slightly increasing. However, the average annual minimum temperature of Nepal is decreasing in the recent years. As the data shows, the lowest average annual minimum temperature was $1.77234^{\circ} \mathrm{C}$ in 1995. And the highest average annual minimum temperature was recorded to be $6.42022^{\circ} \mathrm{C}$ in 2006 . The minimum temperature has decreased to $2.54133^{\circ} \mathrm{C}$ in 2015 from $4.2314^{\circ} \mathrm{C}$ in 2014 .

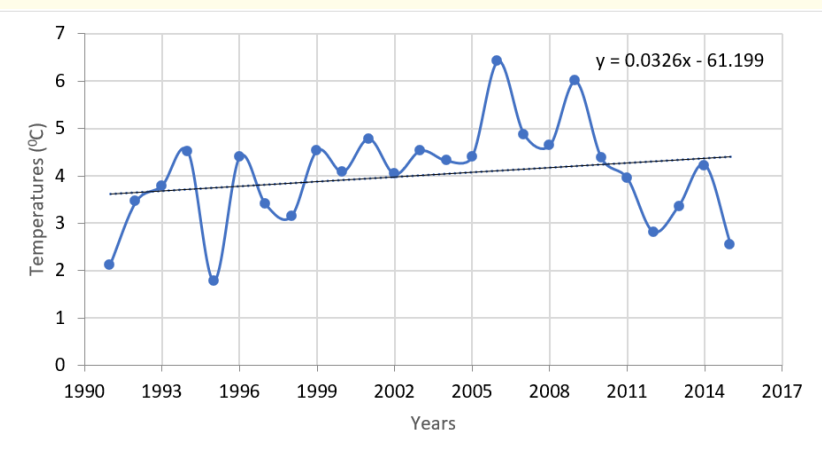

Chart 2: Average annual minimum temperatures in Nepal (1991-2015).

The effect of increasing minimum temperatures can be highly noticed in the temperate crops in Nepal. Temperate crops like Apple, Pear, Peach etc. require chilling temperature to break dormancy in the winter season but due to the increase in average annual minimum temperature, the essentiality of artificial dormancy is seen. Although, the minimum temperature in an average is increasing slightly, the minimum temperature within years is fluctuating at higher amount. The differences between the average annual minimum temperatures are noticed very high. As seen in the chart, the difference between the average annual minimum temperatures in 3 years (2009-2012) is 3.178910C. The effect of low temperature on plants can be blackening of the tissues and death of the plant due to the freezing of tissues.
Chart-3 deals with the average annual precipitation in Nepal. It shows the erratic behavior of precipitation in Nepal in the recent years. The rainfall has been fluctuating at a very high rate according to the data. Highest raining month showed less rainfall in another year. The highest average precipitation recorded till date was 138.2731 in 2011 whereas the lowest was 45.97193 in 2014 . However, fluctuation can be seen on different months. Like, the average monthly precipitation in July,2008 was 256.336 whereas precipitation on the same month next year was recorded to be 68.5289 . This proves the irregularity in precipitation every year.

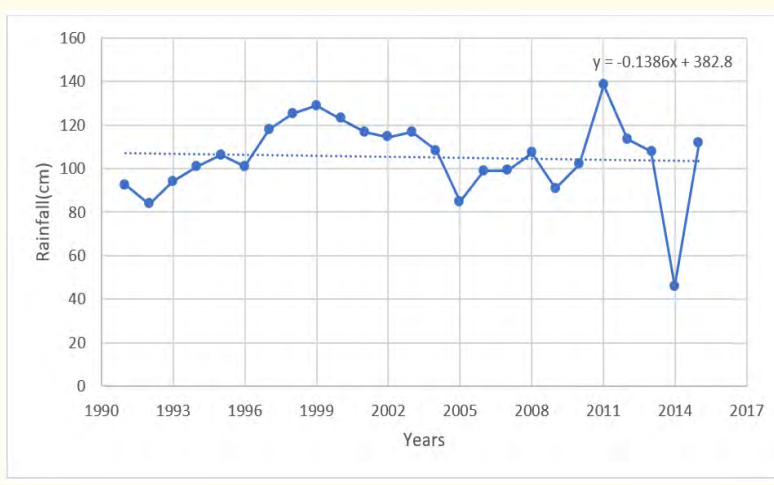

Chart 3: Average annual precipitation in Nepal (1991-2015).

Rainfall variability from season to season greatly affects soil water availability to crops, and thus pose crop production risks. Ideally, crop cultivations should be situated in areas with high rainfall with low variability [16]. The precipitation during the crucial stages of plant growth is necessary. Every crop has its own critical stage for irrigation. Nepal is generally dependent on rainfall for irrigation. But, due to the erratic pattern of rainfall, the crops are adversely affected. They are not getting required amount of water for their proper growth and development.

\section{General impacts in Nepal}

Due to the higher amount of rainfall and maximum temperatures, the number of natural calamities like flood, melting of snow, glaciers lakes outburst flood has been noticed countrywide. This is affecting agriculture in a hazardous way. Altogether 14 glacial lake outburst floods (GLOFs) have happened between 1935 and 1991 in Nepal. In total, 21 GLOFs have been identified as being potentially dangerous at present [17]. An emission of $1465 \mathrm{Gg}$ (Giga gram) of $\mathrm{CO}_{2}$ was estimated in 1994 caused by combustion of fossil fuel. Similarly, the average production of methane from livestock and agriculture was estimated $867 \mathrm{Gg}$ in the same year [18]. Global climate change model has predicted that the rainy season in Nepal will be extended to June from July with more rainfall and the winter will be drier. Twenty-four hours of extreme precipitation analyses indicate the whole of the Terai, which is the food bowl of Nepal, is susceptible to floods [18]. Not only the mountain regions, but the tour- 
ist places like Chitwan in Terai is also affected by climate change and global warming. The temperature in Chitwan is increasing day by day and people are feeling warmer days than ever. Similarly, in 2012, Pokhara experienced devastating flood originated from Glacier Lake Outburst Flood. In 2013, avalanches killed 16 people in Mt. Everest that was associated with climate change. In 2012, more than 60 people, three Ukrainian tourists among them, were killed in the popular Mount Annapurna region in western Nepal [19]. The changing climate has delayed the monsoon rendering thousands of hectares of farm land fallow and reducing the productivity of the land due to lack of rain.

According to ICIMOD, Temperature in Nepal is increased by $3 \%$ whereas the prediction was done that the annual irrigation water demand will increase by $11 \%$, keeping other parameters of water demand constant.

\section{Impacts on agriculture and plants}

It has been found that the increasing temperature and carbondioxide emission are somehow helpful in the production of some crops to some extent. The helpfulness can be seen by the enhancement of photosynthetic processes, water use efficiency, soil microbial activities which results in the increase in agricultural productivity. Whereas the negative impacts of climate change are decrease in grain filling period caused by the increase in respiration process, fertilizer use efficiencies, increase in insect pest population, increase in soil erosion, evapo-transpiration and decrease in mineral nutrient content in several crops.

Eastern Terai faced rain deficit in the year 2005/06 by early monsoon and crop production reduced by $12.5 \%$ on national basis. Nearly $10 \%$ of Agri- land were left fallow due to rain deficit but mid-western Terai faced heavy rain with floods, which reduced production by $30 \%$ in the year [20]. Adverse effect of climate change could lead to the extinction of some indigenous crop varieties such as many aromatic rice varieties including Basmati rice, some local wheat, maize, and other agricultural crops as well [21]. It was also observed that a severe winter cold wave in $\mathrm{Ne}$ pal in 1998 had negative impacts on agricultural productivity and showed a high percentage of yield reduction for potato $(27.8 \%)$, leaf mustard (36.5\%), mustard seed (11.2\%), lentil (37.6\%), and chickpea (38\%) [22].

According to (Lone, Qayoom and Singh) [23], It has been proved experimentally that for single leaf photosynthesis rate increases with increased $\mathrm{CO}_{2}$ level especially in $\mathrm{C} 3$ plants. When these experiments were extended to crop levels, it was found that increased $\mathrm{CO}_{2}$ to $600 \mathrm{ppm}$ increased the number of tillers and branches and hence greater solar radiation interception and resulting about $25 \%$ that increased $\mathrm{CO}_{2}$ reduced transpiration due to decreased stomata aperture and may result in higher Water-Use Efficiency (WUE).

\section{Climate change adaptations}

It is a major challenge for Nepal for adaptation to climate change in agriculture and related sectors because majority of populations in Nepal are still depending on the climate-sensitive agriculture. For the adaptation to the climate change, Nepalese government has introduced a policy that is included in the legislative framework. The policy is "Climate Change Policy" which was introduced in March, 2011. As a preliminary preparation of climate change policy, Nepal has prepared its National Adaptation Programme of Action (NAPA) for adapting to extreme climate events and variability through an extensive country-driven consultative process which was shared with Parties to the UNFCCC in November 2010 and also prepared a National Framework for Local Adaptation Plan for Action (LAPA) with the twin objectives of implementing adaptation actions, and integrating climate change into local development planning and implementation [24]. The LAPA Framework ensures that the process of integrating climate change resilience from localto-national planning is bottom-up, inclusive, responsive and flexible. It identifies local adaptation needs that focuses on reducing local climate risks and vulnerabilities, and increasing resilience using the seven steps.

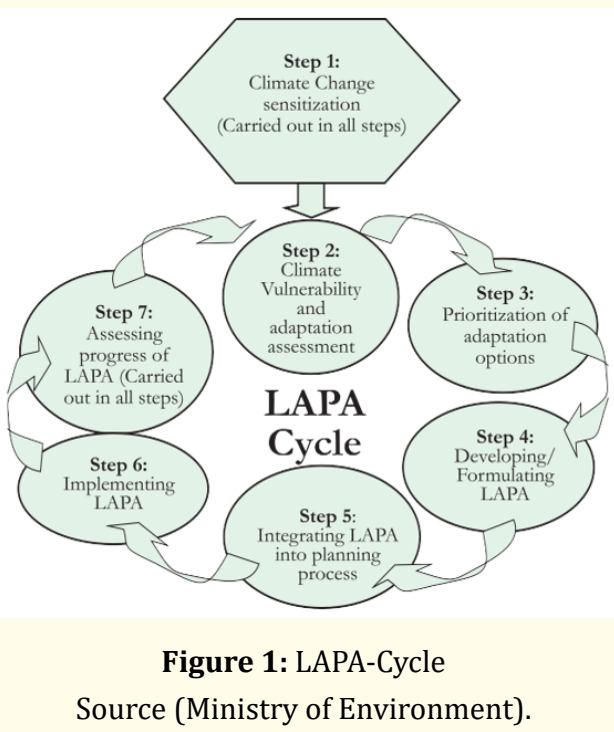

One of the major goals of the climate change policy was Initiation of community based local adaptation actions as mentioned in the National Adaptation Programme of Action (NAPA) through managing financial resources by 2011 which was initiated through the Nepal Climate Change Support Programme (NCCSP) in 2013 Under which, 70 LAPAs are currently being implemented and an additional 30 are prepared. Similarly, Ecosystem based adaptation and Glacial lake outburst flood projects are in implementation [25]. The climate change policy, 2011 goaled to assess the losses and benefits from climate change in various geographical areas and 
development sectors by 2013. As an initiative for this, one assessment was undertaken at the request of GoN, focusing on agriculture, hydro electricity and water-induced disasters [25]. Similarly, the idea of climate smart agriculture is also developed to adapt the climate change and global warming. Mitigation of climate change effects are also taken under consideration and various projects are developed for this.

\section{Conclusion}

Climate change is not a small topic. The effects of climate change are inevitable. Nepal is subjected towards high vulnerability of climate change because it is a developing country. Effects have been already noticed in different sectors especially in Agriculture. Irregularity in Rainfall pattern, Temperature rise have started to create problems to several farmers of the country. However, change in the carbon dioxide composition have some beneficial impacts to some crops in short period of time. But These effects can never be totally eradicated but they can be minimized through proper planning and policies. For this, Government of Nepal has formulated policies regarding climate change with the hope of minimizing these effects. As to conclude, climate change has negative impact on agriculture in the long run. So, this is the time to think in a serious and sustainable way.

\section{Bibliography}

1. MFSC/GEF/UNDP. "Nepal Biodiversity Strategy". Ministry of Forests and Soil Conservation (2002).

2. WCMC. Priorities for Conserving global species richness and endemism (Caldecott, Julian Oliver). Cambridge: World Conservation Press (1994).

3. Manandhar NP. "Plants and people of Nepal". Timber Press (2002).

4. Rana RB., et al. "On-farm conservation of indigenous vegetables by strengthening community basedseed banking in Seti River Valley, Pokhara, Nepal”. LI-BIRD Technical Paper number 3 (1998).

5. FAO. "Nepal at glance". 2018.

6. The Official Portal of Government of Nepal. "Econonmic Scenario of Agriculture". Agriculture Sector (2018).

7. Acharya SP and GR Bhatta. "Impact of Climate Change on Agricultural Growth in Nepal”. NRB Economic Review vol 25 (n.d.).

8. MoAD. "Impact of Climate change fiance in agriculture on the poor". (2018).

9. Shrestha., et al. "Bathymetric surver of Tsho Rolpa Glacier Lake-2002". (2002).

10. NCVST. "Vulnerability Through the Eyes of the Vulnerable". (2009).
11. Barlett R., et al. "Climate change impacts and adaptation in Nepal". Colombo: International Water Management project (2010).

12. Malla G. "Climate Change and Its Impact on Nepalese Agriculture". The Journal of Agriculture and Environment (2009): 6271.

13. Fonseca AE and ME Westgate. "Relationship between desiccation and viability of maize pollen". Field Crops Research 94.2-3 (2005): 114-125.

14. Commuri PD and RJ Jones. "High Temperatures during Endosperm Cell Division in Maize”. Crop Science 41.1 (2001): 11221130.

15. Hatfield JL and KJ. et al. Boote. "Climate Impacts on Agriculture: Implications for Crop Production". Agronomy Journal (2011): 351-370.

16. Koo Jawoo. "Rainfall Variability and Crop Yield Potential". Washingtoon D.C. HarvestChoice, 92010).

17. Mool PK., et al. "Inventory of Glaciers, glacial lakes, glacial lake outburst floods monitoring and early warning system in the Hindu-Kush Himalayan region, Nepal". Kathmandu,Nepal: ICIMOD, (2001).

18. Upadhyay Bidur Prasad. "Climate Change Impact on Nepal". Kathmandu: The Himalayan Times (2009).

19. Bhatta Sagarika. "Climate change impact in Nepal". South Asia Journal (2016).

20. Regmi HR. "Effect of unusual weather on cereal crops production and household food security". The Journal of Agriculture and Environment 8 (2007): 20-29.

21. Paudel MN. "Adaptation mechanisms in agriculture for climate change in Nepal". Hydro Nepal, Special issue (2012): 82-85.

22. NARC, (Nepal Agricultural research Council). "Annual Reports 1987-1998". (2010).

23. Lone Bilal Ahmad., et al. "Climate Change and Its Impact on Crop Productivity". British Journal of Applied Science and Technology (2017): 1-15.

24. Ministry of Environment. "National Adaptation Programme of Action to climate change". (2010).

25. Lamsal K., et al. "Climate Change Policy in Nepal: Challenges, Opportunities and Imperative". Pokhara, Nepal: LI-BIRD (2014).

Volume 3 Issue 7 July 2019

(C) All rights are reserved by Sudhan Bhusal. 